\title{
Upaya Pengembangan Sektor Pariwisata Melalui Peran Kreativitas Pemuda
}

\section{Tourism Sector Development Efforts through the Role of Youth Creativity}

\author{
Arif akbar, R. Hamdani Harahap* \& Rujiman \\ Program Studi Magister Perencanaan Pembangunan Wilayah Dan Pedesaan, \\ Sekolah Pascasarjana, Universitas Sumatera Utara, Indonesia
}

Diterima: 03 Juni 2021; Direview: 03 Juni 2021; Disetujui: 29 November 2021

\begin{abstract}
Abstrak
Tujuan dari penelitian ini untuk melihat kreativitas pemuda dalam mengembangkan Kawasan wisata Danau Toba yang berada di wilayah Kecamatan Muara. Metode yang digunakan dalam penelitian ini adalah metode deskriptif dengan pendekatan kualitatif. Penelitian ini melihat bagaimana daya tarik wisata yang dimiliki Kecamatan Muara baik dari sisi attraction, amenity, accessibility, maupun ancilliary. Ada tiga peran dan kreativitas yang dilakukan pemuda selaku motor pembangunan Kawasan Danau Toba di Kecamatan Muara. Pertama kreativitas pemuda sebagai dinamisator dimana dalam pelaksanaannya pemuda membentuk Komunitas Muara Inspirasi sebagai wadah pelaksanaan kegiatan-kegiatan kreatif yang berfungsi untuk mengoptimalkan segala sumber daya pemuda yang ada. Kedua kreativitas pemuda sebagai Motivator dimana dalam pelaksanaannya pemuda terus mendorong dan menyakinkan masyarakat yang tinggal di Kecamatan Muara untuk membangun ekonomi mandiri dengan membuat usaha-usaha lokal seperti membuat penginapan, rumah makan dan pembuatan ulos. Selain itu pemuda Muara Insipirasi juga turut memotivasi anak-anak diusia sekolah untuk menambah pengetahuan melalui rumah baca. Peran dan kreativitas ketiga adalah pemuda sebagai Inovator dimana pemuda Muara Inspirasi memberikan gambaran inovasi kepada Ibu-ibu penenun Ulos untuk menjadi media promosi dan cerita histori Danau Toba di Kecamatan Muara.

Kata Kunci: Kreativitas Pemuda; Pengembangan Pariwisata; Muara Inspirasi
\end{abstract}

\begin{abstract}
The purpose of this study was to see the creativity of youth in developing the Lake Toba tourist area in Muara Regency. The method used in this study is a descriptive method with a qualitative approach. This study looks at how the tourist attraction of Muara Regency in terms of attractiveness, amenities, accessibility, and support. There are three roles and creativity carried out by youth as the motor of the development of the Lake Toba Region in Muara Regency. First, youth creativity as a driving force, in which youth implementation forms the Muara Inspirasi Community as a forum for implementing creative activities that functions to optimize all existing youth resources. Second, youth creativity as a motivator where in practice the youth continue to encourage and hope that the people living in Muara Regency to build an independent economy by making local businesses such as making lodging, restaurants and making ulos. In addition, the youth of Muara Insipirasi also motivate school-age children to increase their knowledge through reading houses. The third role and creativity is youth as innovators where Muara Inspirasi youth provide an overview of innovation to ulos weavers to become promotional media and historical stories of Lake Toba in Muara Regency. Muara Insipirasi youth also motivate school-age children to increase their knowledge through reading houses. The third role and creativity is youth as innovators where Muara Inspirasi youth provide an overview of innovation to ulos weavers to become promotional media and historical stories of Lake Toba in Muara Regency. Muara Insipirasi youth also motivates school-age children to increase their knowledge through reading houses. The third role is youth as innovators where Muara Inspirasi youth provide an overview of innovation to ulos weavers to become promotional media and historical stories of Lake Toba in Muara Regency.

Keywords: Youth Creativity; Tourism Development; Muara Inspiration
\end{abstract}

How to Cite: Akbar, A. Harahap, R.H. \& Rujiman (2022). Upaya Pengembangan Sektor Pariwisata Melalui Peran Kreativitas Pemuda. PERSPEKTIF, 11 (1): 69-76

*Corresponding author:

ISSN 2085-0328 (Print)

E-mail: rhamdani@usu.ac.id

ISSN 2541-5913 (online) 


\section{PENDAHULUAN}

Pemuda adalah salah satu pilar yang memiliki peran besar dalam perjalanan kehidupan berbangsa dan bernegara sehingga maju mundurnya suatu negara sedikit banyak ditentukan oleh pemikiran dan kontribusi aktif dari pemuda di negara tersebut. Begitu juga dalam lingkup kehidupan bermasyarakat, pemuda merupakan satu identitas yang potensial dalam tatanan masyarakat sebagai penerus cita-cita perjuangan bangsa dan sumber insani bagi pembangunan bangsa, karena pemuda sebagai harapan bangsa dapat diartikan bahwa siapa yang menguasai pemuda akan menguasai masa depan (Satries, 2009).

Menurut Naibaho, dkk (2016) Pemuda merupakan unsur yang menarik dan esensial dalam suatu gerakan perubahan, maka menarik untuk dikaji karena di dalam jiwa pemuda terdapat kerelaan berkorban demi cita-cita dan di dalam pemuda terdapat api idealisme yang tidak menuntut balasan, baik berupa uang atau kedudukan. Bersama pemuda kita menentang segala kekuasaan yang tiran, bersama pemuda, kapal yang bernama Indonesia akan ditentukan maju, diam atau tenggelam.

Jika merujuk Undang-undang nomor 40 tahun 2009 dan Peraturan Menteri Pemuda dan Olahraga nomor 59 tahun 2013 menyatakan bahwa, warga negara atau penduduk yang berusia 16-30 tahun dinamakan pemuda. (Kartasasmita, 1997) mengatakan pada akhirnya yang paling penting, paling dibutuhkan dan dinanti-nantikan masyarakat adalah kepeloporan dan kepemimpinan dalam upaya memperbaiki kehidupan dan meningkatkan kesejahteraan rakyat menurut cita-cita keadilan sosial.

Pemuda adalah ujung tombak dalam era pembangunan saat ini. Peran dan dukungan pemuda sangat diharapkan dalam mengisi pembangunan. Oleh karena itu, keterlibatan pemuda menjadi sangat penting dalam mewujudkan percepatan pembangunan diantaranya pengembangan kepariwisataan.

Saat ini sektor wisata memegang peran penting dan strategis untuk menunjang perekonomian nasional, sektor ini dapat menyerap tenaga kerja dengan dibukanya berbagai tempat wisata yang baru, juga dapat mendorong investasi yang secara langsung maupun tidak langsung dapat meningkatkan devisa negara. Untuk mendorong berbagai program wisata pemerintah saat ini membuat berbagai rencana kebijakan. Salah satu kebijakan itu adalah menggali potensi, menginventarisir, dan mengembangkan potensi wisata baik potensi alam yang ada serta budaya dan keanekaragaman lainnya. Kabupaten Tapanuli Utara memiliki banyak potensi sektor wisata. Kabupaten Tapanuli Utara memiliki peninggalan sejarah yang terus dilestarikan secara turun temurun, keindahan alam yang sangat mempesona yang mampu menarik banyak orang untuk berkujung kesana. Salah satunya adalah Kecamatan Muara, dimana kecamatan ini adalah satunyasatunya kecamatan di Kabupaten Tapanuli Utara yang bersinggungan langsung dengan Danau Toba. Danau Toba merupakan salah satu destinasi pariwisata yang masuk dalam daftar 10 destinasi pariwisata super-prioritas Indonesia dan termasuk dalam geopark global network-Unesco.

Pariwisata merupakan salah satu industri penggerak perekonomian suatu negara. Perekonomian Indonesia juga mengalami peningkatan karena didukung aktifitas sektor pariwisata dari aktifitas wisatawan. Berkembangnya sektor pariwisata dapat memberikan manfaat ekonomi khususnya kepada masyarakat lokal yang tinggal dikawasan pariwisata (Suharyanto, et al., 2020; Lubis, et al., 2020; Suharyanto, et al., 2019).

Dibanyak negara, sektor kepariwisataan telah mampu menyumbangkan hasil berupa peningkatan ekonomi, sehingga dimasa-masa mendatang semakin banyak negara yang menggantungkan perekonomiannya kepada sektor kepariwisataan disamping sektor industri yang menjadi urutan pertama di banyak negara dunia. Kecenderungan akan semakin meningkatnya kegiatan travelling tidak akan berhenti, dikarenakan tuntutan kebutuhan manusia untuk melakukan kegiatan wisata yang tidak akan pernah mengalami penurunan, bahkan akan selalu mengalami peningkatan setiap tahunnya.

Di era globalisasi dan syarat akan teknologi menjadikan masyarakat lebih beresiko mengalami tekanan dari berbagai faktor, seperti tekanan dari pekerjaan dan lainlain. Berkumpul dengan keluarga dan menyisihkan sedikit waktunya untuk sekedar berwisata adalah hal yang saat ini digemari oleh banyak kalangan sebagai salah satu cara untuk memulihkan fisik dari stress, relaksasi diri, serta menjaga keharmonisan keluarga. 
Sektor pariwisata sebagai kegiatan perekonomian telah menjadi andalan potensial dan prioritas pengembangan bagi sejumlah negara, terlebih negara berkembang seperti Indonesia yang memiliki potensi wilayah yang luas dengan daya tarik wisata yang cukup besar, banyaknya keindahan alam, dan aneka warisan sejarah budaya.

Industri pariwisata merupakan salah satu sarana yang tepat dalam meningkatkan kemajuan ekonomi masyarakat baik lokal maupun global. Tidak dapat dipungkiri bahwa industri pariwisata merupakan sektor ekonomi yang memiliki pertumbuhan yang cukup cepat. Banyaknya lapangan pekerjaan dari industri pariwisata yang muncul mulai dari kegiatan pengadaan jasa akomodasi, Rumah Makan, Layanan Wisata, hingga bisnis Cinderamata telah berhasil membantu pemerintah untuk mengurangi tingginya tingkat pengangguran. Sumbangan devisa bagi kas negara yang terus mengalir juga merupakan salah satu darnpak positif akibat perkembangan industri pariwisata.

Industri pariwisata apabila ditinjau dari segi budaya, secara tidak langsung memberikan peran penting bagi perkembangan budaya Indonesia karena dengan adanya suatu objek wisata maka dapat memperkenalkan keragaman budaya yang dimiliki suatu negara seperti kesenian tradisional, upacara-upacara agama atau adat yang menarik perhatian wisatawan asing dan wisatawan Indonesia. Industri pariwisata yang berkembang dengan pesat memberikan pemahaman dan pengertian antar budaya melalui interaksi pengunjung wisata (turis) dengan masyarakat lokal tempat daerah wisata tersebut berada. Hal tersebut menjadikan para wisatawan dapat mengenal dan menghargai budaya masyarakat setempat dan juga memahami latar belakang budaya lokal yang dianut oleh masyarakat tersebut (Spillane, 1994).

Provinsi Sumatera Utara memiliki banyak daya tarik wisata alam khususnya di Kabupaten Tapanuli Utara yang mempunyai banyak potensi yang bisa diandalkan sebagai salah satu sumber pendapatan daerah, promosi budaya, dan sebagainya. Kecamatan Muara di Kabupaten Tapanuli Utara sangat diuntungkan dengan letak geografis yang berada di daerah pegunungan dan langsung berbatasan dengan Danau Toba, sehingga memiliki banyak objek wisata yang menarik untuk dikunjungi. Karakteristik wilayahnya yang masih alami dan budaya masyarakatnya yang masih banyak berorientasi kepada kearifan lokal menjadikan Kecamatan Muara memiliki berbagai potensi daya tarik wisata yang jika berhasil dikembangkan dapat meningkatkan kesejahteraan masyarakat dan menjadi sumber pendapatan bagi masyarakat.

\section{METODE PENELITIAN}

Penelitian ini menggunakan metode kulitatif dengan pendekatan deskriptif. Metode penelitian kualitatif digunakan karena peneliti ingin mengedepankan adanya proses interaksi serta komunikasi yang mendalam antara peneliti dengan informan. Data yang digunakan dalam penelitian ini, yaitu data primer diperoleh melalui wawancara dan observasi, dan data sekunder diperoleh melalui literatur ilmiah yang telah diterbitkan sebelumnya seperti buku dan jurnal, adapula data sekunder yang diperoleh melalui media massa yaitu internet. Proses yang dilakukan peneliti dalam penelitian ini yaitu: kepustakaan, wawancara, observasi partisipasi, dokumentasi.

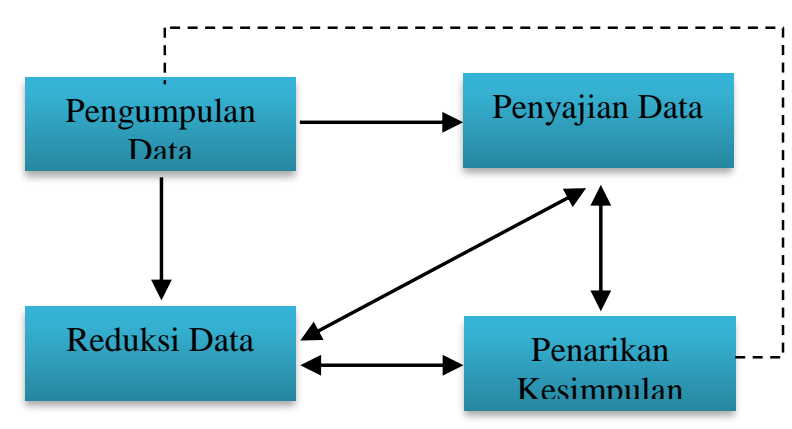

Gambar 1. Model analisis interaktif menurut Milles dan Hubberman

Sumber Gambar (Sugiyono, 2010)

\section{HASIL DAN PEMBAHASAN}

Peran serta keterlibatan dalam kreativitas pemuda untuk pengelolaan kegiatan wisata di Kecamatan Muara menjadi fokus naratif untuk mendapatkan gambaran utuh mengenai bentuk kreativitas pemuda di Kecamatan Muara. Adapun subjek perhatian pada pemuda Kecamatan Muara terintegrasi pada pembahasan mengenai komunitas Muara Inspirasi yang menjadi motor penggerak pemuda Kecamatan Muara dalam kegiatan wisata, edukasi, literasi dan strategi kebudayaan. 
Pemuda Kecamatan Muara sebagaimana yang penulis ketahui selama proses observasi partisipasi adalah komunitas pemuda Kecamatan Muara yang peduli dengan isu pemuda, wisata, edukasi, literasi dan strategi kebudayaan yang adaptif antara kemajuan zaman dan pelestarian nilai tradisi. Adapun informan dan data pada bagian ini merupakan korelasi antara pemuda dan komunitas Muara Inspirasi dalam membangun kreativitas pemuda Kecamatan Muara

\section{Muara Inspirasi; Motor Penggerak Kreativitas Pemuda Muara}

Komunitas Muara Inspirasi adalah komunitas kreativitas pemuda terhadap kehidupan dan pembangunan pariwisata di kecamatan muara, kehadiran muara inspirasi sebagai kumpulan pemuda yang peduli terhadap gerak kehidupan di kecamatan muara. setelah mereka melihat potensi yang dimiliki oleh Kecamatan Muara serta kehadiran beberapa peneliti yang melakukan penelitian di wilayah Kecamatan Muara. Hal ini mendorong untuk lebih giat berkreasi dalam segala bidang dan memberi peran lebih kepada pemudapemudi Kecamatan Muara sebagai motor penggerak kehidupan sosio-kultur. Sejak berdirinya tahun 2018, komunitas Muara Inspirasi telah melakukan beberapa kegiatan yang membawa perubahan pada kehidupan masyarakat Kecamatan Muara, seperti: Proyek Pulang Kampung Ulos - Sandra Niessen, Kapal Baca Tao Toba, Festival Ulos Nusantara, Festival Babi, Festival Alogo adalah kegiatan yang mengikutsertakan pemuda-pemudi Kecamatan Muara secara aktif dan berkreasi mengenai peran pemuda dalam pembangunan Kecamatan Muara.
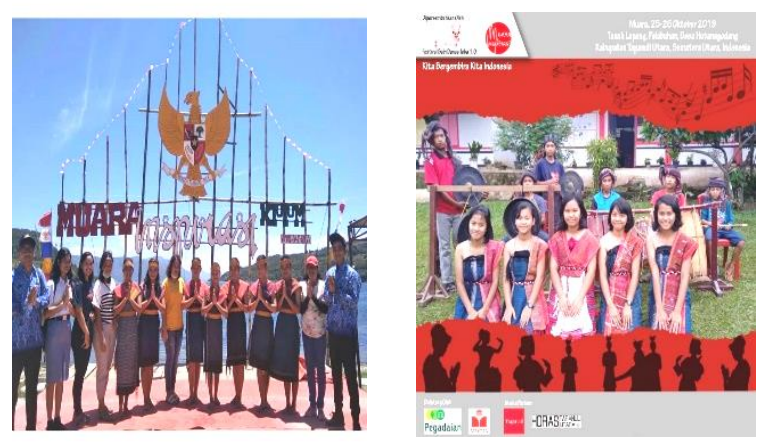
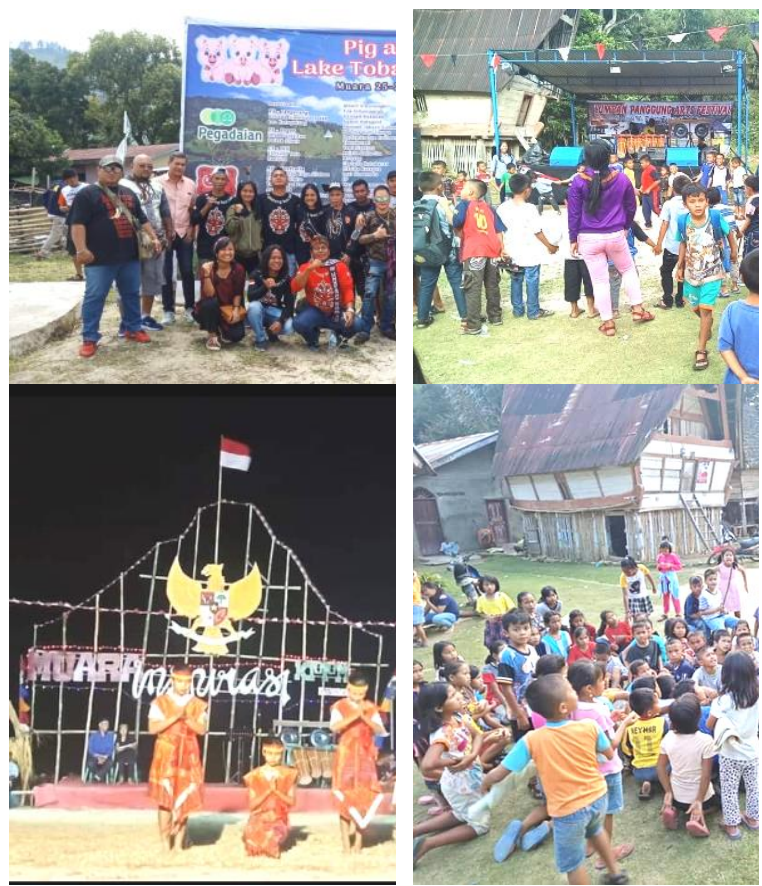

Gambar 2. Beberapa Kegiatan Yang diselenggarakan oleh Muara Inspirasi Sumber Gambar (Peneliti 2021)

Kegiatan-kegiatan tersebut merupakan hasil kerja keras seluruh pengurus Muara Inspirasi. Ishak Aritonang mengatakan seluruh kegiatan yang mereka lakukan hanya bermodal tekad yang kuat. Materi dan tenaga mereka usahakan sendiri hingga akhirnya ada sponsorsponsor yang ingin membantu. Hal itu pun sangat jarang terjadi, dari seluruh kegiatan yang Muara Inspirasi lakukan adalah dari biaya sendiri.

Narasi komunitas Muara Inspirasi adalah pembuka deskripsi mengenai keterlibatan pemuda-pemudi secara aktif di Kecamatan Muara dalam kreativitas dan pembangunan kegiatan wisata lebih lanjut.

\section{Pemuda Sebagai Dinamisator}

Pemuda sebagai dinamisator. Dinamisator dalam bahasa sederhananya adalah penggerak. Pemuda diartikan juga sebagai komunitas penduduk yang mempunyai pikiran-pikiran muda seperti kreatif, inovatif dan konstruktif. Pikiran-pikiran pemuda tersebut maka pemuda akan senantiasa mempunyai kemauan dan kemampuan, ketika kemauan dan kemampuan itu bersatu maka pemuda akan menjadi penggerak.

Semenjak Danau Toba Semakin berkembang sebagai surga baru dari dunia pariwisata, dampak yang dirasakan untuk 
kecamatan Muara tidak sehebat daerah Danau Toba yang lain seperti Parapat, Balige, Samosir dan beberapa derah lainnya. Karena adanya rasa prihatin terhadap kampung halaman yang tidak se-eksis daerah wisata Danau Toba yang lain, akhirnya beberapa orang pemuda terus mengembangkan ekonomi kreatif berbasis pariwisata di Muara. Dimana pemuda dan pemudi yang ada di Kecamatan Muara memiliki obsesi untuk memajukan keadaan sosial serta ekonomi di dalamnya. Pemuda sangat aktif untuk terlibat dalam kegiatan pariwisata serta dalam pengambilan kebijakan dalam berbagi lapisan elemen masyarakat. Tak hanya itu mereka juga aktif dalam kegiatan pelestarian nilai-nilai budaya yang ada sehingga tidak menghilangkan identitas mereka sebagai pemuda lokal.

Para pemuda di Kecamatan Muara akhirnya membentuk komunitas kreatif yakni bernama Muara Inspirasi. Komunitas ini menjadi pengontrol dan pengembang dalam potensi ekowisata yang ada di Muara. Mereka sering melakukakan kegiatan-kegiatan yang kreatif sekaligus menjadi media promosi bagi masyarakat luar agar lebih mengenal potensi wisata dan budaya di Kecamatan Muara. Salah satunya melakukukan festival seni, pagelaran seni, pesta horas, festival tenun, pesta mangalahat horbo, festival babi, festival tenun dan lumban panggung art festival dan masih banyak lagi. Selain itu, kelompok kreatif ini selalu mengajak masyarakat lainnya untuk bekerja sama dan berkolaborasi dengan berbagai lapisan masyarakat lainnya untuk pengembangan wisata yang ada.

Pemuda sebagai dinamisator adalah bentuk keikutsertaan pemuda dalam gerak laju pembangunan di Kecamatan Muara, khususnya yang berkaitan dengan kreativitas pemuda pada kegiatan pariwisata, pemuda adalah pendukung pengembangan pariwisata di Kecamatan Muara, pada setiap kegiatan yang ada di Kecamatan Muara, pemuda selalu menjadi panitia inti dalam proses kegiatan yang ada, pemuda yang maju adalah pemuda yang memberikan ide-ide baru untuk selalu aktif dalam proses pengembangan pariwisata, pemuda juga berkolaborasi dalam semua aspek.

Selain itu, kelompok pemuda ini aktif untuk bergotong royong dan membantu masyarakat tentang hal apapun. Mereka aktif ikut sebagai panitia inti untuk pengembangan wisata yang direncanakan. Sehingga terlibat secara langsung dalam setiap tindakan dan kebijakan yang dibuat. Ini dilakukan karena melihat kondisi yang ada sebelumnya dimana kecamatan Muara belum terlalu dikenal sebagai destinasi favorit dalam dunia pariwisata, masyarakat setempat hanya dijadikan penonton bukan sebagai penggerak dan pengelola. Pemerintah pun acuh tak acuh dalam memperhatikan pengembangan serta fasilitas yang ada. Ini lah sebabnya para pemuda semakin aktif dalam pengorganisasian dan pelestarian wilayah. pemerintah tidak aktif dalam mengadakan kegiatan pariwisata, selalunya menunggu program pusat. Pemuda Kecamatan Muara aktif dan menjemput bola dalam mengadakan kegiatan dan promosi wisata melalui edukasi, literasi sebagai upaya mendorong keaktifan dan kemandirian pemuda.

Mereka juga aktif mendorong masyarakat dalam menciptakan unit usaha yang dapat memenuhi kebutuhan para wisatawan seperti warung makan, penginapan, dan berbagai kebutuhan lainnya.

\section{Pemuda Sebagai Motivator}

Pembangunan merupakan tanggung jawab semua elemen masyarakat, kita tidak boleh membebankan pelaksanaan pembangunan hanya kepada pemerintah. Dalam konteks ini pemuda harus memerankan diri sebagai motivator kepada semua elemen masyarakat untuk mau bersama-sama bahumembahu melaksanakan dan mensukseskan pembangunan. Diawal berdirinya kelompok kreatif, sangat susah untuk mengajak masyarakat agar mau mendirikan ekonomi mandiri yang menggunakan potensi wilayah sendiri. Namun akhirnya dengan sosialisasi, penyuluhan dan pendekatan emosional yang dilakukan, akhirnya Muara Inspirasi berhasil membangun dan mengajak masyarakat untuk membangun ekonomi mandiri dengan membuat usaha tempat penginapan serta produk-produk lokal yang dapat dijual yakni ulos.

Keterlibatan pemuda sebagai motivator terhadap usaha-usaha pembangunan di Kecamatan Muara sudah sangat sering dilakukan, seperti dalam kegiatan gotongroyong maupun dalam kegiatan pembangunan lainnya di Kecamatan Muara. Pemuda Kecamatan Muara juga sering dilibatkan oleh 
pihak pemerintah dalam usaha pembangunan wilayah, walaupun terkadang pada praktiknya terdapat kesalahpahaman diantaranya, seperti tujuan pembangunan yang tidak sesuai dengan asas keterlibatan masyarakat, pembangunan yang tidak tepat sasaran hingga pada kebijakan pariwisata dari pemerintah yang tidak sesuai dengan kondisi di lapangan.

Berkaitan dengan pemuda sebagai motivator, pemuda Kecamatan Muara memiliki korelasi yang kuat terhadap pengembangan pariwisata berbasis masyarakat. Secara sederhana, produk pariwisata secara lokal diartikulasikan dan dikonsumsi, produk wisata dan konsumennya harus visible bagi penduduk lokal yang seringkali sangat sadar terhadap dampak turisme.

Pemuda juga turut memberikan semangat dan motivasi kepada anak-anak Muara dalam hal pendidikan. Mereka membuat kegiatan-kegiatan yang menurutsertakan anakanak sebagai peserta. Muara Inspirasi juga mempunyai rumah baca yang berada di rumah Ishak Aritonang. Siapa saja boleh datang dan membaca buku dikediamannya yang juga dijadikan sekretariat Komunitas Muara Inspirasi.

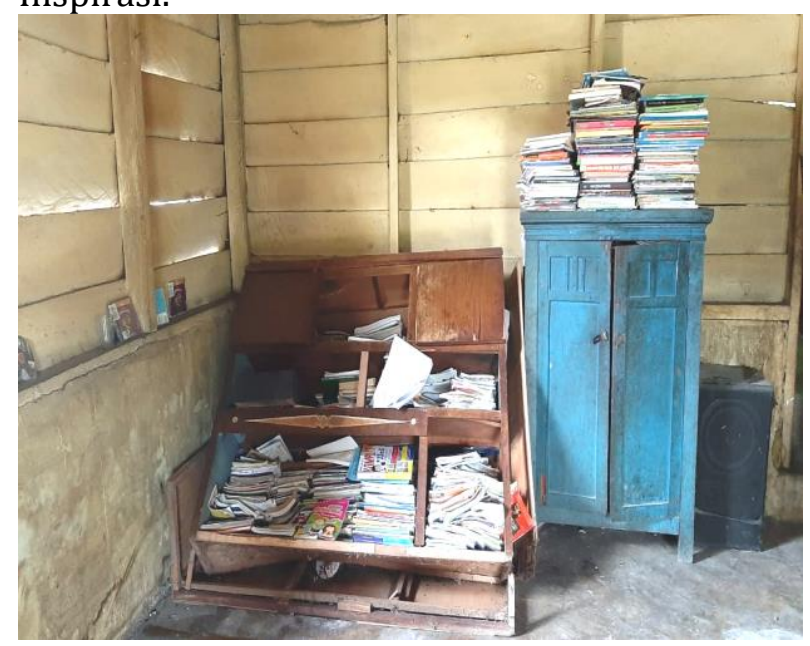

Gambar 3. Koleksi Buku Rumah Baca Muara Inspirasi

Sumber Gambar Peneliti (2021)

Walau dengan kondisi apa adanya, para pemuda Muara Inspirasi dengan penuh semangat memberikan contoh dan dorongan yang baik terhadap anak-anak yang kelak menjadi generasi penerus bangsa. Seluruh buku yang mereka miliki adalah hasil jerih payah dan tanpa bantuan dari pihak manapun. Ishak Aritonang juga berharap adanya perhatian dari Pemerintah ataupun pihak- pihak yang peduli dan mau membantu meningkatkan kualitas rumah baca mereka, mulai dari pengayaan jumlah buku, hingga peningkatan kenyamanan di dalam rumah baca.

\section{Pemuda Sebagai Inovator}

Dalam kajian psikologi pemuda mempunyai karakteristik selalu berpikir rasional dan ideal, karena karakteristik itulah pembaharuan-pembaharuan sering muncul dari pemuda. Karakteristik yang akhirnya melahirkan semangat inovasi harus juga merambah ke sektor pelaksanaan pembangunan. Pemuda dengan jiwa yang tidak pernah puas terhadap satu keberhasilan akan selalu mencari keberhasilan kedua, ketiga dan seterusnya. Hal ini lah yang dilakukan oleh kelompok pemuda di Kecamatan Muara. Selalu mempunyai inovasi baru yang selalu diperuntukkan untuk membangun dan menguatkan potensi Kecamatan Muara.

Contohnya saja pembuatan rumah tenun. Dimana sekaligus menjadi media promosi untuk masyarakat tentang kain tenun seperti ulos yang memiliki kualitas yang baik. Memberikan penyuluhan serta pendidikan kepada ibu-ibu tentang kreativitas seperti memasak yang dimana juga didukung oleh ketua kelompok ibu-ibu yang ada. Hal ini menunjukkan bahwa semakin hari kelompok pemuda kecamatan Muara semakin sadar akan pentingnya pengembangan potensi wisata dan kemampuan masyarakat.

Hal ini tidak hanya menjadi pemasukan bagi perekonomian masyarakat setempat, tapi juga menjadi sebuah gerakan dasar untuk masyarakat agar dapat mengelola sendiri potensi wilyah yang ada.

\section{Pemuda dan Muara Inspirasi; Usaha Pengembangan Pariwisata Berikat}

Weaver (2010) menjelaskan bahwa pariwisata berbasis komunitas (communitybased tourism) pada awal 1980 adalah suatu sine qua non dari pariwisata alternatif. Konsep pariwisata ini diharapkan menjadi alternatif wisata dari wisata massal yang mulai ditinggalkan karena lebih banyak menimbulkan penurunan bahkan perusakan atas lingkungan, baik lingkungan alam maupun lingkungan budaya dan sosial. Sedangkan menurut Hausler (2005) Community-based Tourism merupakan suatu pendekatan 
pembangunan pariwisata yang menekankan pada masyarakat lokal (baik yang terlibat langsung dalam industri pariwisata maupun tidak) dalam bentuk memberikan kesempatan (akses) dalam manajemen dan pembangunan pariwista yang berujung pada pemberdayaan politis melalui kehidupan yang lebih demikratis, termasuk dalam pembagian keuntungan dari kegitan pariwisata yang lebih adil bagi masyarakat lokal.

Dalam pengembangan pariwisata berbasis komunitas (Community-based tourism) diperlukan prinsip-prinsip keberhasilan. Prinsip dasar dari keberhasilan konsep CBT seperti yang diungkapkan oleh The Society of Kanko-Mancizukuri dalam Yotsumoto et al (2016) yaitu sebuah aktivitas yang dilakukan oleh komunitas lokal sebagai aktor utamanya dalam mewujudkan suatu kegiatan yang berbasis nilai kelokalan, seperti alam, budaya, sejarah dan ekonomi lokal. Ditegaskan lagi oleh Wearing (2001) yang menegaskan bahwa sukses atau keberhasilan jangka panjang industri pariwisata sangat tergantung pada tingkat penerimaan dan dukungan dari komunitas lokal. Karena itu, untuk memastikan bahwa pengembangan pariwisata di suatu tempat dapat dikelola dengan baik dan berkelanjutan, maka hal mendasar yang harus diwujudkan untuk mendukung tujuan tersebut adalah bagaimana memfasilitasi keterlibatan yang luas dari komunitas lokal dalam proses pengembangan dan memaksimalkan nilai manfaat sosial dan ekonomi dari kegiatan pariwisata.

Sebagaimana dikemukakan di atas tentang pariwisata berbasis komunitas (Community-based tourism) terdapat beberapa hal yang digaris bawahi. Pengembangan pariwisata telah menuju ke era keberlanjutan (sustainability) dengan menekankan pada aspek ekonomi, sosial dan ekologi yang saling berkaitan erat. Dalam hal ini pengembangan komunitas lokal (social sustainability) akan diselaraskan dengan pengembangan ekologi (enviromental sustainability) sehingga hal ini akan menarik wisatawan untuk berkunjung yang tentunya akan berdampak positif bagi kesejahteraan ekonomi lokal (economic sustainability).

\section{SIMPULAN}

Peran kreativitas pemuda di Kecamatan Muara dalam aspek individu maupun kelompok adalah sosok pemuda yang mengambil peran sebagai agent of change dalam kehidupan sosio-kultur, terutama pada praktik wisata yang sedang berlangsung di Kecamatan Muara. Adapun kreativitas pemuda Kecamatan Muara dalam bentuk realita praktik adalah membentuk wadah komunitas "Muara Inspirasi" sebagai motor penggerak pemuda untuk kembali pulang ke kampung halaman untuk berbagi pengetahuan dan membangun desa. Kreativitas pemuda Kecamatan Muara juga mencakup pada usaha mendukung pariwisata secara langsung melalui melakukan secara swadaya kegiatan festival dengan mengangkat nilai-nilai tradisi sebagai konsumsi wisata dan menghidupkan potensi wisata budaya yang memiliki nilai signifikan pada kegiatan wisata Danau Toba secara umum dan Kecamatan Muara secara khusus, misalnya menawarkan rute perjalanan wisata yang menarik dan melintasi beragam wilayah Kecamatan Muara dengan beragam pengalaman yang berbeda. Beberapa festival yang dibesut oleh pemuda Kecamatan Muara; festival Tenun Nusantara, festival Mangalahat Horbo, Lumban Panggung Art Festival, Pesta Horas, festival Babi adalah hasil kreativitas pemuda Kecamatan Muara yang memiliki arti bagi pengembangan kegiatan wisata di Kecamatan Muara.

Peran pemuda melaksanakan peranannya sebagai dinamisator, innovator dan motivator dalam mengembangkan pariwisata di Kecamatan Muara Kabupaten Tapanuli yaitu kertelibatan aktif pemuda di kalangan sesama pemuda-pemudi di Kecamatan Muara untuk turut-serta dalam pembangunan wilayah Kecamatan Muara. terlihat dari usaha mereka menjadikan pemuda sebagai basis kekuatan pengembangan sumber daya manusia melalui serangkaian usaha; edukasi, literasi dan aksi yang dilakukan baik secara personal maupun komunitas. Langkah strategis dengan menjadikan pemerintah daerah (dalam hal ini perangkat desa dan perangkat kecamatan) sebagai mitra dalam posisi sejajar melalui penawaran program kerjasama, program pembangunan masyarakat desa, kreativitas membuat kegiatan yang melibatkan pemuda dan masyarakat dan kehadiran rumah baca sebagai wacana pengembangan kapasitas pemuda yang dapat mengambil posisi strategis dalam kehidupan bermasyarakat. 


\section{DAFTAR PUSTAKA}

Fahrizal, M.Y, Hendra, Y. \& Hidayat, T.W. (2020). Opini Publik Tentang Destinasi

Hausler, N. 2005. Definition of Community-based tourism. Tourism Forum International at the Reisepavillon. Hanover 6 Februari 2005.

Kartasasmita, Ginandjar. 1997. Pemberdayaan Masyarakat: Konsep Pembangunan Yang Berakar Pada Masyarakat. Jurnal Ilmiah.

Lubis, F.R.A., Suharyanto, A., Effendy, R., Meidasari, V.E., Shahnaz, L. (2020). Role of Facebook Advertising in Promoting Tourism in Asia. International Journal of Psychosocial Rehabilitation, 24(1)

Muzanny, M., Siregar, N., \& Isnaini, I. (2019). Analisis Disiplin Aparatur Sipil Negara pada Badan Kepegawaian Dan Pengembangan Sumber Daya Manusia Kabupaten Aceh Timur. Strukturasi: Jurnal Ilmiah Magister Administrasi Publik, 1(2), 138-146

Naibaho, Robet Rianto, dkk. 2016. Analisis Peran Pemuda Dalam Pembangunan Pariwisata Di Kabupaten Serdang Bedagai. Jurnal Ekonomi, Vol. 19, No. 1, hal. 9

Pariwisata Danau Toba Sebagai Global Geopark Kaldera UNESCO Melalui Website Kompas.Com. Jurnal Ilmu Pemerintahan, Administrasi Publik, Ilmu Komunikasi (JIPIKOM), 2(1) 2020: 19-24,

Satries, Wahyu Ishardino. 2009. Peran Serta Pemuda Dalam Pembangunan Masyarakat. Jurnal Madani Edisi I

Simamora, R.K., dan Rudi S.S., (2016). Peran Pemerintah Daerah dalam Pengembangan Pariwisata Alam dan Budaya di Kabupaten Tapanuli Utara, JPPUMA: Jurnal Ilmu Pemerintahan dan Sosial Politik UMA (Journal of Governance and Political UMA), 4 (1): 79-96.
Sinuhaji, V.V. Siregar, N.S.S. \& Jamil, B. (2019). Aktivitas Komunikasi Pemasaran Dinas Pariwisata Dan Kebudayaan Kabupaten Karo Dalam Meningkatkan Kunjungan Wisatawan (Studi Deskriptif Kualitatif Wisata Bukit Gundaling Berastagi), Administrasi Publik, Ilmu Komunikasi (JIPIKOM), 1(2) 2019: 101114 ,

Spillane, James. 1994. Pariwisata Indonesia, Siasat Ekonomi dan Rekayasa Kebudayaan. Kanisius. Yogyakarta.

Sugiyono. 2010. Metode Penelitian Pendidikan Pendekatan Kuantitatif, kualitatif, dan R\&D. Bandung: Alfabeta

Suharyanto, A. Febryani, A. Wiflihani \& Batubara, B.M. (2019). Village Government Policy on Tourism Management in Situngkir Village Research Article in Proceedings of the 2nd International Conference on Social Sciences and Interdisciplinary Studies (formerly ICCSSIS), ICCSIS 2019, 24-25 October 2019, Medan, North Sumatera, Indonesia

Suharyanto, A., Barus, R. K. I., \& Batubara, B. M. (2020). Photography and Tourism Potential of Denai Kuala Village. Britain International of Humanities and Social Sciences (BIoHS) Journal, 2(1), 100-108.

Syardiansah. (2019). Pengaruh Kuliah Kerja Nyata Mahasiswa Fakultas Ekonomi Universitas Samudra Terhadap Pengembangan Kompetensi Sumber Daya Manusia. Journal of Education, Humaniora and Social Sciences (JEHSS). 1 (3): 148-155.

Wearing, S. 2001. Volunteer Tourism: Experience that makes a difference, Wallingford: CABI

Weaver, D. 2010. Community-based tourism as strategic dead-end. Tourism Recreation Research 35(2), 206-208.

Yotsumoto, Y; Han, J; Hatada, N. 2016. An Overview of Japanese Tourism - Based Community Development: Definitions and Successes. 25(2). 